\title{
TEORÍAS Y ACTITUDES ESCÉPTICAS EN LA ANTIGÜEDAD
}

JUAN A. GARCÍA GONZÁLEZ.

Vamos a hablar aquí de las teorías y actitudes escépticas de la antigüedad, con la idea clara de que fue precisamente en la antigua Grecia donde se forjó esa posición filosófica que conocemos con el nombre de escepticismo.

Quiero decir con ello que el escepticismo moderno, o el escepticismo actual, latente con frecuencia bajo la apelación al relativismo contemporáneo, son especulativamente débiles en comparación con el escepticismo antiguo. Quizás, incluso, porque hoy no se toma conciencia explícita del escepticismo que veladamente se extiende en nuestra cultura; en cambio, los antiguos filósofos griegos sí que tomaron conciencia de su escepticismo, lo desarrollaron sistemáticamente, y lo defendieron hasta el extremo de aplicarlo coherentemente en la práctica. Por esto resulta admirable hoy en día la solidez del escepticismo antiguo. Y, además de por admiración, es oportuno considerarlo porque, como digo, una deriva escéptica se impone ocultamente en nuestra sociedad. 


\section{HISTORIA DEL ESCEPTICISMO ANTIGUO ${ }^{1}$}

Al escepticismo se le pueden buscar muy remotos antecedentes: remontándose a Homero y los siete sabios de Grecia, como hace Diógenes Laercio ${ }^{2}$; o bien señalando, con toda razón, la veta escéptica de los sofistas, sobre todo Protágoras y Gorgias ${ }^{3}$.

Pero, en mi opinión, el antecedente explícito del escepticismo es el mencionado por Cicerón ${ }^{4}$ : Xión de Metrodoro (que floreció a comienzos del s. IV a. de C.). Un discípulo de Demócrito que, en su obra Sobre la naturaleza, llegó a negar hasta la posibilidad de saber que no sabemos. La importancia de este antecedente estriba en el influjo que la escuela atomista tuvo en el escepticismo inicial. Pues Metrodoro fue maestro de Diógenes de Esmirna, éste de Anaxarco de Abdera, y éste finalmente de Pirrón, el padre del escepticismo. A su vez fueron atomistas los primeros discípulos de Pirrón, como Nausifanes de Teos y Hecateo Abderita.

Con todo, la primera etapa escéptica de la historia de la filosofía propiamente acontece en la Grecia clásica, simultánea e inmediatamente después del esplendor de la escuela ateniense (Sócrates, Platón y Aristóteles).

\section{El escepticismo inicial}

En esta primera etapa, a la que llamamos de escepticismo inicial, distinguimos dos momentos sucesivos:

\section{a) El pirronismo}

Es el escepticismo como actitud vital, que tiene una intención más moral que teórica, cual corresponde a la época de las escuelas socráticas menores en la que

1 Como bibliografía de orientación general sugiero:

DIÓGENES LAERCIO: Vidas de los filósofos más ilustres. Porrúa, México, 1984.

FRAILE, G.: Historia de la filosofía. BAC, Madrid 1971; v. I: Grecia y Roma.

HEGEL, G.W.F.: Lecciones sobre la historia de la filosofía. FCE, México, 1981; v. 2.

2 Junto con ellos, Diógenes Laercio recoge, como antecedentes del escepticismo, expresiones de Archíloco, Eurípides, Jenófanes, Zenón, Demócrito, Platón, Eurípides, Empédocles, Heráclito e Hipócrates; cfr. Vidas de los filósofos más ilustres IX, 11, Pirro § 8-9.

3 MILLÁN-PUELLES, A.: Léxico filosófico. Rialp, Madrid, 1984; p. 122.

4 Cfr. Acad. Pr. II 23, 73. 
se encuadra. Sus más significados representantes son Pirrón y su continuador Timón ${ }^{5}$.

- Pirrón de Elis (365-275 a. de C.)

Es el fundador del escepticismo, si bien primero fue pintor ${ }^{6}$. Aunque no escribió nada, abrió una escuela en su ciudad natal sólo unos cinco años antes de la fundación del Liceo aristotélico. Había recibido influencias (por mediación de Brisón, o Drusón, hijo de Estilpón) de la escuela socrática de los megáricos, erística y discutidora hasta la palabrería sofista; y, por el magisterio de Anaxarco de Abdera, del atomismo, al que encontró un sentido moral para desprenderse de las apariencias de los sentidos: a fin de cuentas, si todo se resuelve en átomos... Influencias ambas a las que hay que añadir además las recibidas en un viaje por Asia en el que acompañó a Alejandro Magno, viendo allí magos, brahmanes, faquires y gimnosofistas (sabios desnudos), de cuya actitud ante lo sensible, ilusiones (mayas) para estos orientales, sacó sus propias consecuencias.

Cuentan de él innumerables anécdotas que expresan una forma de vivir indiferente ante lo sensible y que elude el verse afectado por ello. Así, viendo a su maestro Anaxarco caído en el barro, pasó de largo sin socorrelo; o debiendo optar entre limpiar la casa o llevar pollos a la plaza para venderlos, terminó por ponerse a limpiar los pollos. O que no repelió el ataque de un perro; y que permanecía impasible tanto mientras le curaban una llaga de su piel, cuanto si en un viaje por mar una borrasca sacudía su embarcación (en tal circunstancia, puso como modelo la tranquilidad de un cerdo que iba amodorrado en el barco). Cuentan también que no se retiraba si en la calle se cruzaba con carruajes o caballos; y que acometía contra las paredes convencido de la irrealidad de las sensaciones; todo esto naturalmente rodeado de discípulos y amigos que le apartaban de los peligros en los que incurría.

Aunque no sean del todo ciertos estos sucedidos, dan muestra de que el pirronismo más que una doctrina teórica y sistemática es una actitud vital dirigida a la felicidad, y a la búsqueda de ese ideal del sabio autárquico que persiguieron las escuelas socráticas menores, y más las post-aristotélicas. Con todo, también de sus fuentes y de esas anécdotas, se infiere lo que Pirrón sostenía, a saber: que

\footnotetext{
5 Se dice que los discípulos de Pirrón fueron Euriloco, Filón de Atenas, Hecateo Abderita y Nausifanes de Teos; junto con Numenio condiscípulo de Timón. Otros escépticos, discípulos de Timón, son mencionados por Diógenes Laercio: Dioscórides de Chipre, Eufranor de Seleucia, Nicolocho (Neoloco) de Rodas, Praulo (Raylo) de Tróade y Tolomeo de Cirene; cfr. Vidas de los filósofos más ilustres IX, 12, Timón § 6.

6 Una pintura suya, Los lamparistas, adornaba el gimnasio de su ciudad natal, cfr. DIÓGENES LAERCIO: Vidas de los filósofos más ilustres IX, 11, Pirro § 2.
} 
la felicidad consiste en la tranquilidad del espíritu y en la indiferencia ante las turbaciones (ataraxia; concepto también originario, al parecer, de Demócrito; y luego usado por estoicos, epicúreos y escépticos). Según este parecer la fuente de todo infortunio está en el celo, en el sentido más amplio del término; es decir, en toda clase de lazo interno que nos liga a las cosas. En consecuencia la felicidad debe basarse en una perfecta ataraxia, en una constante indiferencia ante todas las cosas ${ }^{7}$. Para lograrla, lo oportuno es abstenerse de juzgar, no pronunciándose a favor ni en contra de nada (afasia) y suspendiendo el asentimiento intelectual (epojé). Con un matiz a señalar: su orientación hacia el conocimiento sensible, que es el que Pirrón más cuestiona y del que aspira a desprenderse.

En la época moderna, el pirronismo fue especialmente valorado por Nietzsche, que lo consideraba como uno de los últimos genuinos representantes de la filosofía griega posterior a la traición cometida por Sócrates y proseguida por Platón. De Pirrón dice Nietzsche que su vida fue una protesta contra la gran doctrina de la identidad entre felicidad, virtud y conocimiento ${ }^{8}$.

- Timón de Fliunte (320-230 a. de C.)

Fue el discípulo más significado de Pirrón. Primero danzarín, luego discípulo de Estilpón, de la escuela de Megara nuevamente, de quien pasó a serlo de Pirrón. Más tarde, y carente de recursos económicos, ejerció como sofista por varios lugares de Grecia; y se enriqueció con ello, estableciéndose finalmente en Atenas, donde permaneció hasta su muerte. A diferencia de Pirrón escribió mucho: dramas, comedias, tragedias; y también obras filosóficas, entre ellas: Apariencias, Sobre las sensaciones, Contra los físicos, etc. Era tuerto; lo que tiene que ver con el título de una de sus obras (Silos, mirada oblicua), en la que se opone a todas las escuelas filosóficas mofándose de ellas. Escribió también polemizando con Arcesilao y defendiendo a Pirrón, pues estos tres escépticos fueron contemporáneos en los comienzos del s. III a. de C.

El escepticismo de Timón tiene otras fuentes -y eso quiere decir otros perfiles- que el pirrónico, pues procede también de la decepción ante la pluralidad de doctrinas filosóficas (pues Timón ejerció como sofista, como ya hemos dicho); a las que califica como dogmáticas, y satiriza y ridiculiza con una ironía algo grosera, siguiendo en cierto modo la actitud burlona de Jenófanes. De las discrepancias entre las distintas escuelas filosóficas deduce la incapacidad de la razón para conocer las cosas. Sus esencias nos son inaprensibles, y debemos

\footnotetext{
7 HOSSENFELDER, M.: Escepticismo. En KRINGS-BAUMGARTNER ET ALTERI: "Conceptos fundamentales de filosofía". Herder, Barcelona, 1977; v. I, p. 647.

$8 \quad$ La voluntad de poder, $\$ 437$.
} 
contentarnos con sus apariencias. Pero, precisamente por ser tales, no debemos dejarnos seducir por ellas; sino permanecer indiferentes, sin afirmar ni negar nada, en silencio, y sin juzgar. El escéptico es un mero espectador impasible. Sobre poco más o menos, los mismos tópicos que Pirrón; pero con un sentido un poco más intelectual, y con una doctrina algo más elaborada.

\section{b) Segundo momento: el escepticismo académico}

Es el escepticismo de la academia media platónica (266-110 a. de C.) ${ }^{9}$ : un escepticismo más teórico, y de cariz relativista y probabilista; encabezado en la segunda academia por Arcesilao, y en la tercera por Carnéades ${ }^{10}$.

- Arcesilao de Pitane (316-241 a. de C.)

Primero fue discípulo del matemático Autólico, antes de trasladarse a Atenas, al Liceo peripatético con Teofrasto. Después pasó a la Academia platónica, de la que fue escolarca desde el 266 a. de C., devolviendo a la academia el esplendor perdido. Gran orador, al que seguía la juventud; muy desprendido, tanto de sí mismo como de sus riquezas; no escribió nada, y murió de haber bebido vino puro en exceso y caído en delirio a los setenta y cinco años ${ }^{11}$.

El escepticismo de Arcesilao es un escepticismo más teórico que el pirrónico. Y, por una parte, es el escepticismo hacia el que derivó el platonismo de la academia media. Según Hegel, a causa del abstraccionismo platónico: que se queda sólo con la idea, prescindiendo de lo sensible y de lo concreto ${ }^{12}$. Y además, porque Arcesilao fue el primero en basar la actitud escéptica en la consideración conjunta de proposiciones contrarias, radicalizando la dialéctica platónica para argüir en forma escéptica, hablando en pro y en contra de una misma cosa.

Hecho sobre el que no quiero pasar sin llamar su atención: porque no es lo mismo no pronunciarse ni a favor ni en contra de nada, como pretendía Pirrón;

\footnotetext{
9 La academia antigua (367-266 a. de C.: de Espeusipo a Crates de Atenas) es la que sigue inmediatamente a Platón. La academia nueva (desde el 110 a. de C.) engloba las llamadas academia cuarta (ecléctica, hasta los siglos. I-II d. de C.) y quinta (neoplatónica). Justiniano clausuró la escuela en el 529 d. de C.

10 Entre Arcesilao y Carnéades median, en el s. III a. de C., Lacides de Cirene, Telekles, Evandros y Hegesinos (Hegesilao) de Pérgamo. Después de Carnéades se citan como escépticos del s. II a. de C. a Carnéades el joven, Crates de Tarso, Clitómaco de Cartago (Asdrúbal) y Cármides (Cármadas).

11 DIÓGENES LAERCIO: Vidas de los filósofos más ilustres IV, 6, Arcesilao § 10.

12 Cfr. Lecciones sobre la historia de la filosofía, $1^{\text {a }}$ parte, sección $2^{\mathrm{a}}, \mathrm{C}, 1, \mathrm{p} .407$.
} 
que pronunciarse dialécticamente a favor y en contra de lo mismo, como hace Arcesilao, y después hará Carnéades.

Pero, por otra parte, el escepticismo de Arcesilao parece que obedece también a otros motivos. Concretamente, a la discusión con los estoicos, y para evitar su dogmatismo. A juicio de San Agustín la escisión de la nueva academia se produjo no tanto contra la antigua doctrina como contra los estoicos. Y la ve oportuna porque convenía refutar y discutir la nueva opinión introducia por Zenón $n^{13}$. La confrontación entre estoicos y académicos se simboliza con las parejas Zenón-Arcesilao, y luego Crisipo-Carnéades.

Y como el estoicismo tiene también una finalidad práctica, Arcesilao se ve obligado, en pugna con él, a justificar la génesis de la acción a espaldas de la verdad; para lo cual apela como motivo de aquélla a lo razonable, lo probable o lo plausible (eulogon, la buena razón), frente a la representación cataléptica de los estoicos: aquélla que produce tal sensación de verdad que es imposible no asentir a ella. La razón probable, en cambio, es suficiente para engendrar la acción práctica, pero no para asegurar la verdad y excluir el error. Según lo expresa San Agustín, llaman los académicos probable o verosímil a lo que, sin asentimiento formal de nuestra parte, basta para movernos a obrar ${ }^{14}$; de aquí la compatibilidad entre lo inesquivable del actuar y la suspensión del juicio de la actitud escéptica.

- Carnéades de Cirene (214-135 a. de C.)

Fue un gran orador y brillante dialéctico. Discípulo del académico Hegesinos y del estoico Diógenes de Babilonia dirigió la tercera academia elevándola a un alto grado de esplendor; pero acabando también con su platonismo, lo que en definitiva acarreará su declive. Se opuso fundamentalmente al estoicismo, en particular de Crisipo; aunque formuló también críticas a la objetividad de las sensaciones contra el epicureismo.

Formó parte (junto con el estoico Diógenes y el peripatético Critolao) de la comisión de tres filósofos enviada a Roma en el 155 a. de C. para pedir la exención de un tributo. Sus dos discursos sobre la justicia, un día uno a favor y al siguiente otro en contra, impresionaron a Catón el Viejo, quien pidió al senado romano que despidiera pronto a los filósofos.

A Carnéades debemos la mayor elaboración conceptual del escepticismo griego inicial; aunque, como no escribió nada, su doctrina sólo la conocemos a través de Cicerón, y por mediación de su discípulo Asdrúbal (quien, en cambio, sí escribió cuatrocientos libros).

13 Contra los académicos II, 6, 14 [BAC, Madrid 1982].

14 Contra los académicos II, 11, 26. 
El polo crítico de su pensamiento es la negación escéptica: la suspensión del asentimiento y del juicio. Para justificarla invalidó todo criterio de verdad; el cual no puede basarse en la sensibilidad, porque es cambiante y engañosa (fuente de representaciones maníacas); ni tampoco en la razón, porque si pretendemos demostrar todo incurrimos en un proceso al infinito, ya que no todo es demostrable. Como prueba de ello, Carnéades remitía a la lucha entre los sistemas filosóficos, y utilizaba sofismas cual el del mentiroso y el del montón de trigo $\left(\right.$ sorites $^{15}$ ) de Eubúlides de Megara, para enredar a la razón consigo misma. Es notable también la crítica de Carnéades a la teología estoica.

En el polo afirmativo de su pensamiento está la teoría de la probabilidad que Carnéades, como Arcesilao, sostiene para justificar la acción práctica a falta de un criterio racional seguro del que derivarla; de tal modo que la acción se aprueba, pero no se asiente a sus principios teóricos. Y caben tres grados en la probabilidad de nuestros juicios prácticos: la simple representación persuasiva o verosimilitud; la representación verosímil coherente con las demás representaciones, es decir, firme; y la versolimilitud examinada y confirmada por otras representaciones, esto es, desarrollada, justificada: que es la que debemos procurar en los asuntos que afectan a nuestra felicidad.

\section{El escepticismo tardío}

El escepticismo reaparece en una segunda etapa, y con mayor intensidad en sus formulaciones teóricas, ya en la decadencia del helenismo.

Decimos que el escepticismo tardío es más elaborado que el inicial, aunque no sea más que porque sus representantes publicaron las obras más significativas del escepticismo (Discursos pirrónicos, Introducción al pirronismo, Esbozos pirrónicos), mientras que ni Pirrón, ni Arcesilao, ni Carnéades escribieron nada. Pero, en cambio, el escepticismo inicial es seguramente más profundo, por su calado vital, y por afrontar las consecuencias del escepticismo en el orden de la acción práctica.

Sea de ello lo que fuere, este escepticismo tardío pero más elaborado se extiende desde el siglo I a. de C. hasta el III d. de C. Entre otros ${ }^{16}$, sus más notables representantes son Enesidemo, Agripa y, sobre todo, Sexto Empírico ${ }^{17}$.

\footnotetext{
15 Término con el que luego se designarán los polisilogismos que suprimen las conclusiones intermedias.

16 Diógenes Laercio enuncia la siguiente cadena de maestros y discípulos que enlaza las dos etapas escépticas. Tras Eufranor de Seleucia vienen Eubolo Alejandrino, Tolomeo, Sarpedón y Heráclides, a quien oyó Enesidemo Gnosio (de Cnosos). Después de éste Zeuxipo Polites, Zeuxis Goniopo y Antíoco Laodiceno; del que fueron discípulos Menodoto
} 
- Enesidemo de Cnosos, Creta (80-40 a. de C.)

Poco sabemos de su vida. Pero sí que enseñó en Alejandría en tiempos de Cicerón; y algunas de las obras que escribió: especialmente los Discursos pirrónicos y la Introducción al pirronismo, obra clave en la que redactó sus diez tropos (giros, razones, lugares, figuras) en defensa de la suspensión escéptica del juicio frente al dogmatismo. Los tropos se agrupan en tres clases: por razón del sujeto que juzga, por razón del objeto juzgado, o por razón de ambos a la vez. Y en último término, según Sexto Empírico, todos se remiten a que el conocimiento es una relación ${ }^{18}$; luego los veremos.

Enesidemo resucita el pirronismo, o cubre bajo dicho nombre su propio pensamiento escéptico. Basándose en Heráclito y su inestabilidad y mutabilidad de las cosas, proclama que no podemos conocerlas, sino sólo declarar cómo se nos aparecen; son, pues, meros fenómenos. En consecuencia, no podemos juzgar sobre su realidad, sino que lo correcto es suspender el juicio.

- Agripa (s. I d. de C.)

Si poco sabemos de Enesidemo, menos aún de Agripa, excepto el hecho de que añadió cinco nuevos tropos a los de Enesidemo. A juicio de Hegel, que en cambio no menciona a Agripa, los diez tropos antiguos revelan carencia de abstracción; mientras que los cinco posteriores responden a la reflexión pensante, y a un mayor grado de desarrollo del pensamiento filosófico ${ }^{19}$; también luego los enunciaremos.

- Sexto Empírico (ss. II-III d. de C.)

Prácticamente sólo sabemos de él que era médico empírico: una corriente escéptica y empirista de la medicina defendida también por Filino de Cos, Heráclides de Tarento y el ya citado (nota 16) Menodoto de Nicomedia. Médicos empiristas eran quienes se atenían a la investigación experimental y a la observación directa de las manifestaciones de las enfermedades, frente a los médicos dogmáticos que se amparaban en la autoridad y en teorías abstractas sobre las causas de las dolencias. Aunque este mismo hecho perfila el escepticismo de Sexto, y en parte el empirismo de toda esta etapa final del escepticismo antiguo, su pensamiento importa tanto por lo que originalmente sostiene, como porque

Nicomediense y Tiodas (Teodos) de Laodicea. Menodoto fue el maestro de Herodoto de Tarso, y éste lo fue de Sexto Empírico, cuyo discípulo fue Saturnino Citenas; cfr. Vidas de los filósofos más ilustres IX, 12, Timón § 7.

17 Contemporáneo de Sexto, otro escéptico a mencionar fue el irónico Luciano de Samosata (125-200 d. de C.).

18 Cfr. Hyp. Pyrr. I, 135-6.

19 Lecciones sobre la historia de la filosofía, $1^{\text {a }}$ parte, sección $2^{\text {a }}$, D, 1-2, pp. 437, 445. 
constituye la fuente principal de información sobre las doctrinas escépticas de la antigüedad.

Escribió seis libros Contra los matemáticos y cinco Contra los dogmatistas; pero sobre todo hay que destacar los tres libros de sus Esbozos (hypotiposys) pirrónicos en los que resume toda la doctrina escéptica. El primero de estos libros expone, frente a los filósofos dogmatistas, el probabilismo de los académicos; a quienes, con todo, no considera verdaderos escépticos. Para definir en cambio al verdadero escéptico, el que ni afirma ni niega nada, acude a los tópicos pirrónicos de la ataraxia y la epojé: el estado de reposo mental por el cual ni afirmamos ni negamos, que es como la define. De acuerdo con estos tópicos, el escéptico es un observador, un buscador y un preguntador. En el libro segundo critica la lógica estoica, en particular los medios de conocimiento (sensación, demostración, definición, etc.) y el criterio de verdad. Y en el tercer libro somete a crítica la física y la ética estoicas (pues los estoicos dividían así la filosofía: en lógica, física y ética).

Sexto acepta la distinción entre los fenómenos y la existencia de las cosas en sí mismas. Y, como empírico que es, acepta la validez de los fenómenos; si bien éstos aseguran solamente el hecho de su aparecer, pero no tienen en cambio la virtud de autentificar la existencia real de las cosas. Por su parte, la razón tampoco puede llegar a justificarla; porque, de acuerdo con el conocido principio escéptico del que hace uso: a toda razón se opone otra de igual valor. Se excluye así la posibilidad de establecer ningún dogma, ninguna tesis racional, y el escepticismo deriva hacia un fenomenismo.

Curioso, y llamaré también aquí su atención: porque Pirrón era más bien enemigo de los fenómenos sensibles, y tal postura fue el comienzo de su escepticismo.

Con todo, se mantiene el ideal de la ataraxia, de la imperturbabilidad del ánimo. Pero en un sentido distinto; porque la tranquilidad del espíritu no se consigue, como en Pirrón, por no verse afectados por las cosas; sino, más bien a la inversa, obrando de acuerdo con los impulsos naturales que éstas nos provocan, aunque moderadamente; comportándose además conforme con las leyes, costumbres y usos de los pueblos; y despreciando finalmente esas filosofías dogmáticas que pretenden conocer aquello a lo que no se puede llegar. Para permanecer inalterables, estos escépticos toman sus decisiones según la experiencia cotidiana de la vida, y según la costumbre y ley de los padres ${ }^{20}$. En suma, una indiferencia la de estos empiristas rayana en el abandono: renunciar a la

20 HOSSENFELDER, M.: Escepticismo, o.c., p. 648. 
filosofía y vivir en lo inmediato, sin preocupaciones. A esto condujo el escepticismo tardío.

$* * * * * * * * * *$

En estas dos etapas que hemos relatado se integran los cuarentaiún escépticos más conocidos de la antigüedad: Metrodoro, el precursor, doce pirrónicos, diez académicos y dieciocho empiristas del helenismo tardío. De ellos, los más importantes son los mencionados.

\section{AÑADIDOS SOBRE LA DOCTRINA ESCÉPTICA}

Y después de mencionarlos, quiero llamar su atención sobre el distinto aspecto que presentan el escepticismo pirrónico, el probabilismo de la academia y el fenomenismo del helenismo tardío; las tres formas básicas del escepticismo antiguo. A este respecto conviene recordar que a los escépticos se les conocía además por otras tres denominaciones ${ }^{21}$ : ble;

- efécticos: en tanto que juzgan que todo es incognoscible e incomprensi-

- aporéticos: por cuanto ven todo como problemático y dudoso;

- y zetéticos: como inspeccionadores y buscadores que no hallan lo que persiguen.

Cada una de estas denominaciones destaca una peculiar faceta de la actitud escéptica. Porque no es lo mismo el comportamiento apático de Pirrón, que la dialéctica aporética de Carnéades; ni la indiferencia del espectador ausente que mantiene Timón, que la argumentación contra toda clase de teorías de Sexto Empírico. Todas ellas son actitudes manifestativas del escepticismo, pero de un escepticismo de distinto calado. Más vital y centrado en lo sensible el escepticismo inicial, más teórico e intelectualmente desarrollado el tardío.

Efectivamente, el escéptico ha sido definido como el que mira cuidadosamente, el que examina atentamente, antes de pronunciarse sobre nada o antes de tomar ninguna decisión ${ }^{22}$. Definición en la cual se indica su vertiente teórica (el no pronunciarse sobre nada), y su otra vertiente más bien práctica (relativa a

21 Cfr. DIÓGENES LAERCIO: Vidas de los filósofos más ilustres IX, 11, Pirro § 7.

22 FERRATER MORA, J.: Diccionario de filosofía abreviado. Edhasa/Sudamericana, Barcelona 1980; p. 456. 
la toma de decisiones). En su vertiente teórica, el escepticismo defiende la concepción de que la verdad de un juicio no es cognoscible ${ }^{23}$. Mientras que en su vertiente práctica el escepticismo consiste radicalmente en la negación de la posibilidad de la certeza absoluta o metafísica ${ }^{24}$; negación que comporta la falta de convicción, la inseguridad, en orden a la génesis de la acción.

Paralelamente, el término escepticismo se puede suponer derivado, en un sentido práctico y subjetivo, del adjetivo griego "esceptikos", que procede a su vez del infinitivo "esceptomai", cuyo sentido es el de dudar o vacilar ${ }^{25}$. Pero también se lo puede entender derivado, en otro sentido más objetivo y teórico, del sustantivo "skepsis", que significa la vista, la inspección; simplemente el ver, el contemplar, el mirar ${ }^{26}$ (como en la palabra castellana telescopio).

Y no es indiferente la articulación de estos dos sentidos del escepticismo. Porque cabe, en un sentido práctico y vital, negar la verdad para evitar la falsa seguridad de la certeza subjetiva (como parece recomendar el pirronismo); tanto como también cabe, en un sentido más teórico e intelectual, negar la posibilidad de la certeza por desconfiar de la verdad objetiva (como parece sugerir el fenomenismo de los empíricos).

En cualquier caso, la discusión de estos extremos, como significando que ni siquiera la escéptica negación de la verdad y la certeza paraliza la actividad del entendimiento, tiene que ver con ese mayor desarrollo teórico del escepticismo tardío que hemos mencionado.

A él se deben también los conocidos tropos escépticos. Los tropos de los escépticos son los giros ("tropoi") a través de los cuales se llega al retraimiento de la anuencia, como dice $\mathrm{Hegel}^{27}$; o bien las ambigüedades y contrariedades que hay en nuestras especulaciones, y que quitan por sí mismas la creencia en ellas, como lo afirma Diógenes Laercio ${ }^{28}$. Son los siguientes, diez de Enesidemo y cinco de Agripa:

De Enesidemo, y prescindiendo en parte del orden de los tropos ${ }^{29}$ :

\footnotetext{
23 HOSSENFELDER, M.: Escepticismo, o.c., p.639.

24 MILLÁN-PUELLES, A.: Léxico filosófico, o.c., p. 121.

25 MILLÁN-PUELLES, A.: Léxico filosófico, o.c., p. 122.

26 HEIDEGGER, M.: El concepto hegeliano de la experiencia. En Sendas perdidas. Losa-

da, Buenos Aires, 1979; p. 129.

27 Lecciones sobre la historia de la filosofía, $1^{\text {a }}$ parte, sección $2^{\mathrm{a}}, \mathrm{D}, \mathrm{pp} .435$.

28 Vidas de los filósofos más ilustres IX, 11, Pirro $§ 12$.

29 La numeración de estos tropos es distinta en Enesidemo, Favorino de Arlés (s. I d.C.), Sexto Empírico y Diógenes Laercio; cfr. DIÓGENES LAERCIO: Vidas de los filósofos más ilustres IX, 11, Pirro § 18.
} 
$1^{\circ} \quad$ La diversidad de los organismos animales, que ocasiona distintas percepciones del exterior.

$2^{\circ} \quad$ La diversidad de los caracteres humanos, a la que se debe la pluralidad irreductible de apreciaciones entre los hombres.

$3^{\circ} \quad$ La pluralidad y diversidad de los órganos cognoscitivos, que nos proporcionan diversas informaciones de las cosas, diferentes y no siempre compatibles.

$4^{\circ} \quad$ Las distintas circunstancias del cognoscente, que le hacen percibir de distinta manera las mismas cosas.

$5^{\circ} \quad$ La perspectividad del espacio, que hace variar las noticias que recibimos de las cosas.

$6^{\circ} \quad$ La mezcla de cosas, o la complejidad objetiva y subjetiva, que impide que percibamos una información aislada y nítidamente (clara y distinta, que diría Descartes; y a la que aspiraba su escepticismo metódico).

$7^{\circ} \quad$ La variación y diversidad en la cantidad de las cosas, que afecta a la noticia que recibimos de ellas.

$8^{\circ} \quad$ La relatividad de todas las cosas, en cuya virtud unas remiten a otras.

$9^{\circ} \quad$ La frecuencia o rareza de los acontecimientos, que nos hace carecer de la perspectiva adecuada para juzgarlos.

$10^{\circ} \quad$ La multiplicidad de preferencias, usos y costumbres de los hombres, en la que se basan sus distintas opiniones.

De Agripa:

$1^{\circ} \quad$ La diferencia entre las opiniones de los hombres, que no llegan a un acuerdo entre ellos.

$2^{\circ} \quad$ El proceso al infinito en nuestras argumentaciones, que las hace inconcluyentes.

$3^{\circ} \quad$ La relatividad universal, en virtud de la cual todo depende del punto de vista del observador.

$4^{\circ} \quad$ La ausencia de axiomas y consiguiente universalidad de las hipótesis y suposiciones, que torna carente de necesidad nuestros conocimientos.

$5^{\circ} \quad$ El dialelo, o círculo vicioso en el argumentar, que hace vanos nuestros razonamientos por estar recíprocamente sustentados.

Hegel, basándose en Sexto Empírico ${ }^{30}$, concatena de una singular manera estos últimos cinco tropos como para resumir en esquema la argumentación es-

30 Cfr. Hyp. Pyrr. I, 169-77. 
céptica $^{31}$; y concluye que los defectos del dogmatismo (metafísica intelectiva, dice) son dos, a la postre: la demostración infinita, y las premisas hipotéticas e inmediatas $^{32}$.

Por otro lado, además de estos quince tropos, y de los sofismas a los que retóricamente apelan los escépticos (por ejemplo Carnéades), hay algunos tópicos comunes en los discursos y argumentaciones escépticas. Como van dirigidos principalmente contra la filosofía estoica, aunque ya hemos registrado también algunas otras referencias al pensamiento epicúreo y demás filosofías de la época (platónica, peripatética, etc.), destacan las críticas a su teología (Sexto Empírico) y a la noción de providencia estoica (Carnéades).

Pero además son tópicos del pensamiento escéptico ${ }^{33}$ :

- en el ámbito lógico, la negación de toda forma de demostración y de la intencionalidad de los signos;

- en el orden físico, la negación de cualquier tipo de causalidad, e incluso del movimiento;

- y en el plano ético, la negación de la objetividad, y hasta de la realidad, de la moralidad, bondad o maldad, de los actos humanos; y de sus cualidades éticas, en particular la justicia.

Añadiré que, fijándonos en estos tropos y tópicos, podremos seguramente percibir más de cerca el velado escepticismo en el que hoy en día nos movemos; porque varios de ellos son comúnmente aceptados en la actualidad, bajo esa denominación con que nos caracterizamos de pluralismo democrático ${ }^{34}$.

\section{INTERPRETACIÓN DEL ESCEPTICISMO ANTIGUO}

Con ser el escepticismo antiguo un movimiento filosófico tan importante, quizás se le ha prestado poca atención y más bien se han despreciado sus planteamientos; si exceptuamos el combativo escrito Contra los Académicos ${ }^{35} \mathrm{de}$

31 Cfr. Lecciones sobre la historia de la filosofía, $1^{\mathrm{a}}$ parte, sección $2^{\mathrm{a}}$, D, in fine, pp. 447 ss.

32 Cfr. Lecciones sobre la historia de la filosofía, $1^{\mathrm{a}}$ parte, sección $2^{\mathrm{a}}$, D, in fine, p. 451.

33 Cfr. DIÓGENES LAERCIO: Vidas de los filósofos más ilustres IX, 11, Pirro § 20-30.

34 Balmes decía, en el s. XIX, que el escepticismo es una de las plagas características de la época y uno de los más terribles castigos que ha descargado Dios sobre el humano linaje (Cartas a un escéptico en materia de religión I, Obras X, p. 26)

35 Este escrito no contiene el conocido si enim fallor sum agustiniano. Para encontrar este acceso agustiniano a la subjetividad desde una actitud escéptica es preciso leer Soliloquia II, 
San Agustín, escrito los días 11, 12, 20, 21 y 22 de noviembre del 386 d. de C.: año que podemos considerar como el punto final del escepticismo antiguo.

En términos especulativos, la más notable interpretación que tenemos de él nos la ha legado Hegel, quien se ha ocupado del escepticismo en tres lugares que nos interesan: (a) al exponer el escepticismo antiguo en sus Lecciones sobre la historia de la filosofía (y dedicándole un número de páginas similar al que dedica a toda la escolástica medieval $\left.{ }^{36}\right)$; y al interpretar el escepticismo como experiencia de la conciencia en su Fenomenología del espíritu: por una parte (b), en la Introducción, pues la ciencia de la experiencia de la conciencia puede entenderse, ella misma, como la consumación del escepticismo; y por otra parte (c), al final del estudio de la autoconciencia, al tratar de su libertad y después de examinar el estoicismo ${ }^{37}$. Por su parte, Heidegger ha glosado en El concepto hegeliano de la experiencia (1942-3) $)^{38}$ la interpretación hegeliana de aquella consumación del escepticismo.

a) En su exposición de la historia de la filosofía, Hegel entiende que el escepticismo antiguo consiste en creer que cuando desaparece lo objetivo, lo que se tenía por verdad, el ser, o lo general, todo lo determinado, todo lo afirmativo; y cuando el espíritu retrae su asentimiento, la conciencia de sí mismo logra por sí misma un estado de seguridad de ánimo y de inmutabilidad de sí mis$m a^{39}$. Con otras palabras: la negación de la certeza y de la verdad de los objetos conocidos conduce a aislar la subjetividad del espíritu. Como confirmación de esta interpretación podríamos recordar las filosofías de San Agustín o Descartes, que descubren la existencia de la subjetividad pensante en la experiencia de la duda escéptica y el engaño.

c) Esa experiencia de la propia subjetividad pensante (la inmutable y verdadera certeza de sí misma, dirá Hegel), es también el balance de su estudio del escepticismo como figura de la conciencia; sólo que ahora considerado el escepticismo como un concreto momento del proceso generador de la autoconciencia, entre el estoicismo y la conciencia desgarrada: tres momentos a través de los

\footnotetext{
1, 1 (si non esses falli omnino non posses); De libero arbitrio II, 3, 7; De Trinitate XV, 12, 21 ; etc.

36 Cfr. Lecciones sobre la historia de la filosofía, $1^{\text {a }}$ parte, sección $2^{\text {a }}$, C y D, pp. 405-59.

37 Cfr. Fenomenología del espíritu (FCE, Madrid 1981) IV, B, 2; pp. 124-8.

38 Este ensayo se recoge en Sendas perdidas, o.c. Heidegger tiene también un comentario a La Fenomenología del espíritu de Hegel (1930-31); pero en él sólo llega a los primeros parágrafos de la autoconciencia, sin alcanzar la dialéctica del amo y el esclavo, ni el estoicismo y escepticismo.

39 Lecciones sobre la historia de la filosofía, $1^{\text {a }}$ parte, sección $2^{\text {a }}$, D, p. 431.
} 
cuales lo que se alcanza en rigor es la libertad de la autoconciencia. El escepticismo es justamente el ejercicio y realización de esta libertad.

Como figura de la conciencia:

El escepticismo es la realización de aquello de que el estoicismo era solamente el concepto. Pues así como el estoicismo corresponde al concepto de la conciencia independiente, que se revelaba como la relación entre el señorío y la servidumbre, el escepticismo corresponde a la realización de esta conciencia (...);

A la que no acaece que desaparezca ante ella, sin que sepa cómo, lo que es verdadero y real; sino que, en la certeza de su libertad, ella misma hace que desaparezca eso otro que se presenta como real (...);

Por tanto, la autoconciencia escéptica experimenta, en las mutaciones de todo cuanto trata de consolidarse ante ella, su propia libertad como una libertad que ella misma se ha dado y mantenido; la autoconciencia escéptica es esta ataraxia del pensamiento que se piensa a sí mismo, la inmutable y verdadera certeza de sí misma ${ }^{40}$.

Pero, con todo, y en la medida en que, con este ejercicio de la libertad de la autoconciencia, hemos perdido el término objetivo del conocimiento, en el escepticismo la conciencia se experimenta como una conciencia contradictoria en sí misma. Pues, como ha señalado Valls, con el escepticismo la conciencia descubre todo su poder negativo en relación con el mundo; pero en definitiva esa grandeza suya se convierte en servidumbre, porque sin mundo se pierde también a sí misma ${ }^{41}$. De este manera, dice Hegel, la duplicación que antes aparecía repartida entre dos singulares, el señor y el siervo, se resume ahora en uno solo; se hace de este modo presente (...) la conciencia desventurada ${ }^{42}$.

b) Finalmente, la causa del escepticismo, o la interpretación última y más profunda de su sentido, la expone Hegel en la Introducción de la Fenomenología del espíritu (la que comenta Heidegger), cuando hace equivaler toda su fenomenología, como ciencia de la experiencia de la conciencia, con la consumación del escepticismo.

El escepticismo que era sólo una figura de la conciencia incompleta, un punto de vista unilateral, ve siempre solamente la pura nada en lo conocido; pero entonces tiene un significado puramente negativo, y es para la conciencia más bien la pérdida de sí misma, ya que por ese camino pierde también su verdad.

40 Fenomenología del espíritu IV, B, 2; pp. 124, 125, 126.

41 VALLS PLANA, R.: Del yo al nosotros (Lectura de la fenomenología del espíritu de Hegel).PPU, Barcelona, 1994; p. 143.

42 Fenomenología del espíritu IV, B, 2; pp. 127, 128. 
Por eso dice Hegel que es el camino de la duda, o más propiamente el camino de la desesperación.

Pero sucede que la conciencia es para sí misma su concepto, la meta necesariamente implícita en el saber ${ }^{43}$. Y por ello la consumación del escepticismo estriba en descubrir en ella lo absoluto, a través de todas sus manifestaciones; tal es el resultado al que se dirige la entera Fenomenología del espíritu.

Mas entonces, como Heidegger ha comentado, la skepsis es mirada que busca lo infinito, lo absoluto; y prescinde de la objetividad inmediata, o duda de ella y la niega, porque no satisface sus requerimientos, justamente por ser finita. Pero en tanto que nuestra esencia pertenece a la parusía de lo absoluto, dice Heidegger, es posible y hasta obligada la inversión de la conciencia natural que Hegel practica en su fenomenología, y que por eso es la consumación del escepticismo: pues esa inversión es la "skepsis" en la absolutez. En palabras de Heidegger: la conciencia natural sufre entonces una violencia; esta violencia consiste en el imperio de la inquietud en la conciencia; y ese imperio es la voluntad de lo absoluto. Por tanto, la inversión de la conciencia es la consumación del ver de la "skepsis", que ve sólo en la medida en que ya se ha provisto previamente de la absolutez ${ }^{44}$.

En suma, Hegel aprecia en el escepticismo antiguo el descubrimiento de la subjetividad pensante (a). Pero mientras el escéptico mantenga una actitud puramente negativa, sólo ejerce y realiza la libertad de la autoconciencia (c). La consumación del escepticismo (b), en cambio, estriba más bien en descubrir el carácter absoluto e infinito de la conciencia, superior a toda objetivación en la que se muestre. A la postre, es el deseo de absoluto, el afán de infinito, el motor de la actitud escéptica. Como decía Heidegger la "skepsis" es la realización del ver en lo absoluto ${ }^{45}$. Se niegan la certeza y la verdad finitas porque se anhela la autoconciencia absoluta. Tanto deseo de conocer, de conocerse, que lo finito que nos aparece y en lo que nos encontramos no llega a satisfacernos.

Con todo, el indudable sentido positivo de esta interpretación hegeliana del escepticismo, que lo remite a la infinitud del inteligir, no nos parece razón suficiente para justificar la actitud escéptica. Porque, en último término, una infinita capacidad cognoscente, una mirada que anhela toda la luz, una skepsis instalada en lo absoluto, resulta tanto más carente de sentido cuanto menos verdad le hagamos capaz de encontrar. ¿Para qué una poderosa mirada si

43 Cfr. Fenomenología del espíritu, Introducción; pp. 54-55.

44 HEIDEGGER, M.: El concepto hegeliano de la experiencia, o.c., pp. 160, 136, 161.

45 HEIDEGGER, M.: El concepto hegeliano de la experiencia, o.c., p. 172. 
no hay nada que ver?. No tiene sentido descubrir la propia subjetividad al precio de renunciar al medio en el cual habríamos de desplegarla.

$* * * * * * * * * *$

Por otra parte, la observación nietzscheana de que el pirronismo comporta la ruptura de la asociación entre felicidad y conocimiento, nos parece un juicio bien certero en orden a describir la realidad efectiva del escepticismo, tanto antiguo como moderno: la pretensión de vivir a espaldas de la verdad. Además de la vida del propio Pirrón, y del ocaso de la academia platónica, ya hemos mencionado también la deriva indolente que adoptó el escepticismo empírico del helenismo tardío. Pero esta cuestión nietzscheana oculta una reducción de la trascendentalidad de la verdad, de acuerdo con la cual la vida práctica de los hombres puede quedar al margen de ella.

Mas ésta fue una posición ya ponderada por San Agustín cuando se planteaba: si, aun sin poseer la verdad podemos ser felices, ¿creéis que será necesario su conocimiento?; asunto del cual dice que se trata de una cuestión muy importante, digna de la más escrupulosa discusión ${ }^{46}$. A tal discusión obedece su primer libro contra los académicos. Y en él concluye que una vida desentendida de la verdad es imposible, si consideramos que la sabiduría es el camino recto de la vida ${ }^{47}$. La verdad abarca también el vivir humano. Incluso más: la verdad personal, la de cada quien, es superior a la verdad de las cosas. El nietzscheano aprecio de Pirrón no tiene, pues, un sólido fundamento.

Los otros dos libros de esa obra agustiniana establecen, por una parte, la existencia de la verdad, en discusión con la academia platónica (libro II ${ }^{48}$; y por

46 Contra los académicos, I, II, 5 y 6, pp. 76 y 78.

47 Contra los académicos, I, V, 13, p. 87.

48 Contra el probabilismo sostiene que qui nihil approbat, nihil agit (Contra los académi$\cos$, III, 15, 33). 
otra, la posibilidad humana de encontrar esa verdad, o al menos de buscarla (libro III) ${ }^{49}$, como sintetizando los dos libros precedentes.

Juan A. García González. Universidad de Málaga

49 La sabiduría no sólo es la ciencia, sino también la inquisición de las cosas divinas y humanas. (Contra los académicos I, 8, 23). 